\title{
MARKETING COMMUNICATION IN THE VISIT PHASE THROUGH GUEST.NET - AN IN- DESTINATION, LOCATION-BASED SYSTEM AT MAISTRA HOTEL CHAIN IN CROATIA
}

\section{Iva Slivar}

(1) Juraj Dobrila University of Pula, Faculty of economics and tourism "Dr. Mijo Mirković"

Iva Slivar

Juraj Dobrila University of Pula, Faculty of economics and tourism "Dr. Mijo Mirković" islivar@unipu.hr

Article info

Paper category: Preliminary paper

Received: 11.8.2018.

Accepted: $28.9 \cdot 2018$.

JEl classification: M31, Z33, Z39

Keywords

Consumer Journey in Tourism; Visit Phase; Information Distribution; Geolocation-based

Website; Information in the Tourist Destination; Hotel Chains; In-house Promotion;

Travel Planning in situ 


\section{ABSTRACT}

Hoteliers have always endeavoured to retain guests within their facilities, to profit maximally by offering them additional services. Informing guests of various options is performed within in-house marketing techniques, whereas some are ICT based.

Purpose. Hotel chain websites are aimed at the acquisition of guests and as such are inadequate for displaying detailed, service and current information that guests need during their stay in a tourist destination (e.g. happy hour offer at the lobby bar). What about information provided to guests once in the tourist destination? This paper will present one such solution: the Guest.net. It is an in-destination, location-based website accessible from all Maistra Inc. properties, representing a good solution for hotel chains with various nearby positioned tourism facilities aimed at retaining guests within chain facilities.

Design/Methodology/Approach. The approach used in this paper is the case study method.

Findings and Implications. Klante, Kroschel and Bolls theoretical information model (2004) was expanded by adding the planning in situ phase in tourism. Benefits of the application of similar guest services for hotel chains have been listed.

Limitations. Limitations steam from the case study method and relate to the minor geographical area researched.

Originality. There is an evident lack in research of customers in tourism during the visit phase, regarding their decision making process, especially in the evaluation of alternatives and their purchase decision in situ (Law, Buhalis, Cobanoglu, 2014), thus this paper broadens the identified gap in the information collection phase in the destination. 


\section{INTRODUCTION}

Information about the next holiday destination are not difficult to find. Websites of DMOs (Destination Marketing/Management Organisations), tourism providers, various forums etc. provide information from weather forecasts to attractions. But what happens to detailed and specific information in tourism once tourists reach the desired tourism destination? For instance, where is the cash register to buy the tickets of a certain tourist attraction, are credit card payments accepted or should one go to the ATM first and where is the nearest ATM? We have relied on passers-by or professional employees in tourism, the latter are however stationary based in their working places and we have to find them in the first place. The internet is ideal for the distribution of information on tourism products, and the emergence of mobile internet has given it a powerful momentum (Ružić, Turkalj, Biloš, 2014), resulting in an increase of Location based Services (LBS) ${ }^{1}$ (Talaat, Fahmi, Marzouk, 2015). The "instant information support of smartphones enables tourists to more effectively solve problems, share experiences and 'store' memories" (Wang, Park, Fesenmaier, 2012).

This paper deals with in-destination information and how hoteliers can supply guests with such information. The success of the process of exchange of such information in marketing communication in-situ is also measured by achieved goals: the tourism providers should reach an increase of economic and non-economic measures, while tourist should satisfy thier information needs.

In-destination specific information at disposal of guests are an important factor affecting the whole tourist experience and future tourist behaviour. There is a significant difference between information that tourists need before deciding to purchase their holiday and information they need during their stay in the tourism destination. The latter do not primarily have only a promotional and acquisitional purpose but, are aimed at making tourists' stay easier by helping them orientate themselves, plan their daily movements and of course, aimed at increasing tourism spending beyond accommodation and F\&B. Nevertheless, communication in a tourist destination is a neglected topic both in the scientific and professional tourism literature (Law, Buhalis, Cobanoglu, 2014), which is reflected in the frugal literature review that follows.

The aim of this paper is to present a case example of an in-destination system of Maistra Inc. Rovinj, which provides location-relevant information about the tourist offer of this hotel chain, as well as other relevant information to guests during their stay in the two nearby tourism destinations of Rovinj and Vrsar (Croatia) where the hotelier operates.

The paper is conceived in four parts, whereas the first is the introduction. The second chapter deals with relevant literature focusing on marketing information in

1 Location-based Services "as services are to provide information stored in a database. This information can be created, compiled, selected, or filtered in the light of the current location of the mobile use" (Essayad, 2011) 
the destination and DMS (Destination Management System). The focus of this paper is on the importance of providing information to tourists during the stay in the destination rather than on the system itself or similar solutions (e.g. mobile applications, QR codes, etc.). The third part gives an overview of the case study - the Guest.net followed by concluding remarks and discussion (forth chapter).

\section{THEORETICAL REVIEW}

\subsection{Marketing communication}

Marketing communication is the process of exchange of information ${ }^{2}$ with the purpose of achieving certain effects (Kesić, 1997). The communication object is a product or service unlike in corporate-oriented communication. Its focus is mainly on generating and maintaining demand and product or service positioning, "persuading and reminding the target public" (Križman Pavlović, 2008); as opposed to corporate communications dealing with issues such as acquisitions and mergers, social responsibility etc.

The key elements of the marketing communication process are: the sender, the recipient, the message, the communication channel, and the effects (Schultz and Schultz, 2004:160). Communication channels usually are different media, although it may be the vendor itself. Medias which reach a wide audience in different geographic areas are known as mass media (e.g. radio, television and newspapers), while media which allow two-way communication, such as the Internet or the phone, are called interactive media. The expanded communication model includes other elements such as encoding, decoding, and noise / interference in communication (Schultz and Schultz (2004:160). For a more complete understanding of the communication process, ,it is paramount to know the social context of the sender and the recipient; the symbolic and structural meaning of the message; the ability of the recipient to understand the message and the learned reactions; in order to be able to analyse, with an acceptable certainty, the results of the communication" (Kesić, 1997).

Within the message, as a communication element, there are three groups of factors affecting the ultimate outcome (Kesić, 1997):

(1) the structure of the message (content and form: arguments, making conclusions or releasing that audience, presentation order, colour / tone choice, typography / style of presentation, visual / clothing, etc.),

(2) choice of appeal (e.g. appeal to humour, sex, ecology) and

(3) choice of message or signage system (verbal and non-verbal). Communication effects can result in changes in the mind, attitude, and ultimate audience behaviour.

2 Every information is data, but only data useful in decision making for the receiver is called information. 
One of the most well-known classifications of marketing communication is the mass one (indirect and one-way) and communication one-to-one, characterized by the „presence" of the recipient and the sender.

Another dual marketing communication division distinguishes: symbolic (promotional) marketing communication and functional (related to other components of the marketing mix), i.e. communication in the narrower and wider sense (Kesić, 1997, Garača, 2008). Thus, for instance, the packaging of the product has its own communication function, as well as the pricing policy, the choice of distribution partners, the arrangement of stores and other distribution elements - also play their role in forming the image of the company and its products.

There is a dispute weather promotion and marketing communications are synonyms (as promotion is defined as communication with the market). For some, promotion is a narrower concept of marketing communication and, according to a somewhat outdated understanding, focuses on persuasion, excluding the informative component. According to the key elements of the marketing communication mix, it includes: advertising, public relations, sales promotion, personal sales and direct marketing (Kesić, 1997:346). In fact, marketing communication includes all the four classic elements of the promotional mix to which direct marketing is added, as a new paradigm of two-way communication. In addition to the above elements of the communication mix, other communication tools such as events, sponsorships, fairs, personal recommendations etc. are also included (Kotler, Keller 2009).

As for tourism, marketing communications helps to establish a more complete and successful mutual relationship between tourism providers and tourists by (Senečić, Vukonić, 1997):

- establishing mutual relationships

- maintaining such flow of information that allows for exchange

- creating a conscious and informed buyer and seller

- improving the decision-making process

- making the whole process of exchange on the tourist market is as effective as possible.

Furthermore, it can be added also, according to UNESCO's World heritage sustainable tourism online toolkit, that the ultimate goal of communication (i.e. in tourism) should be to move a potential visitor from knowing very little to a deeper understanding of people and place, actively behaving in a more sustainable manner while visiting, and ultimately becoming a champion of the destination". In order to achieve that, adequate in-situ information are an essential prerequisite. 


\subsection{Information in the destination}

The goals of marketing communication are different in relation to the different phases of the customer journey. According to the WTO (2008), there are five key phases of the customer journey in tourism: 1) dream and select, 2) planning, 3) booking, 4) visit and 5) post visit recollection and recommendation. The first three phases can be summarised into the pre-buying phase. From the standpoint of the offer side, there are three key marketing communication activities performed by tourism providers according to the stage of the customer buying cycle: acquisition, in-destination provision and retention (Chaffey et al., 2006).

In the in-destination phase, there are three key moments to address (Klantel, Kroschel, Boll, 2004): the orientation phase (tourists acquire familiarity within the area), the movement phase (focused on finding the right way) and the information phase (discovering more deeply the reached amenity and absorbing information about it). The first critical moment is the provision of hard data (opening hours, modality of payment, transport options, parking availability, accessibility etc.) enabling decision making in order to move on from the orientation phase to the movement phase.

It is necessary to cherish the so-called "in-destination" communication as it provides information to tourists during their stay in the tourist destination. Special attention should be paid to ensure that the information provided are not the same as the tourist information available to them from their homes, prior to the visit, as they have already collected those information. Information in the destination must strive to expand the knowledge and experience of tourists about the attractions and events they are interested in. It is an imperative in order to make it easier for visitors to access their desired activities and facilities as to avoid the loss of time and physical effort they have to invest in satisfying their needs (Ortega and Rodrigues, 2007). Despite the lack of representation of this topic in tourism research, it has great significance from the point of view of tourist experience and satisfaction as well as in the creation of loyalty to a particular tourist destination. Accordingly, it can also be argued that information contribute greatly to the future increase in tourist demand, especially in the context of positive recommendations encouraging other prospect customers.

Ortega and Rodrigues (2007) analysed the importance of information about the destination offer and common information about hotel services available to tourists in Spain (over 3500 respondents). The variables used in the research included two forms of information sources: a) information about tourist destination offers (local attraction brochures available at the reception desk, and a 10/15 minute local attraction movie on the hotel TV and b) information about 13 common hotel services (e.g. value-saving safe in the hotel room, indoor gym, sauna, fitness spa, library, playroom, internet connection in the room, child care etc.). Guests paid most atten- 
tion to information about the tourist destination, primarily presented in brochures, then to those presented in the video projection. The affective and cognitive effects of information use during a vacation were researched by Voght and Steward (1998). Namely, the same travel information may be used repeatedly before and during a vacation with different levels of satisfaction.

Travel is clearly an educational experience as tourists learn and discover more information about the destination and gain skills (Voght, Steward, 1998). Tourists are attracted to the destination by certain elements of attractiveness and during their stay they get to know about other tourism products and experience also other elements, thanks to various sources of information, which will be presented below.

There are numerous ways of getting in-destination information and these are divided into two groups: offline and online sources of information. For the sake of brevity, only some of the most commonly used tools and channels of communication will be mentioned.

\subsection{Typical offline sources of information in the destination}

Besides typical tools of promotion such as brochures, video etc., those specific in tourism will be mentioned further (Križman Pavlović, 2008, Slivar Tiganj, 2012, Vavrečka, Mezuláník, 2016):

- Tourist signalization

- Informing at reception / Guest relations and tourism offices / DMOs

- Tourist guides and locals

- Printed materials (brochures, posters, outdoor advertising etc.)

- Photo, Videos, (interactive) projections, Digital signage (a specialized form of information technology for displaying video or multimedia content in public places for informational or advertising purposes)

- Mass media besides Internet based ones

- In-house Promotion / POS (Poin of Sale) e.g. indoor television in hotel rooms

- satellite navigation (the most known system is GPS - Global Positioning System)

\subsection{Typical online sources of information in the destination}

Consumers are very skilled in collecting information independently. Among various online tools, some typical are listed (Slivar Tiganj, 2012, Ružić, Biloš, Turkalj, 2014, WTO, 2008, pp. 20.):

- Tourist information websites (whereas some have overgrown into DMS Destination Management Systems)

- social media and web.2.o. travel websites etc.

- mobile applications 
- QR (Quick Response) codes

- digital brochures, e-zines etc.

- timely, location-based offers sent to mobile devices by visitors, by SMS or by e-mail

- travel planners ${ }^{3}$ (in various formats or as functionalities of websites)...

- info kiosks / interactive info points etc.

There are many techniques and methods which can be applied in combination to the above listed tools, such as the previously mentioned, location-based marketing. It implies the distribution of targeted marketing messages according to the location of users and has strongly evolved since the advent of mobile devices (Buckowski, 2011). The mix of mobile marketing, contextual marketing and location-based advertising, generated the concept of location-based marketing ( $\mathrm{Li}$ 2011). A similar concept is proximity marketing, which refferers to the distribution of localized marketing messages to customers based on their proximity to the merchant (Levesque, Boeck, 2015) and in terms of delivery it might be push or pull based (Ojala, Kruger, Kostakos and Valkama, 2012). In the selected case study, Guest.Net was a location-based website using Wi-Fi to determine the location of the user. The approach was push based.

\subsection{DMS (Destination Management System)}

Tourist information systems are also known as Destination Marketing System, Destination database, Visitor Information System or simply DMS (Destination Management System) (Slivar Tiganj, 2013). These represent not merely a collection of information and products about the tourism destination, but make the latter available to purchase (Werthner and Klein 1999; O Connor and Frew, 1999).

The requirements of a DMS haven't essentially changed much over time and include (Gerdes, 1998, Wayne, 1991):

- the organization and consolidation of information about the tourist destination, its products and vacation packages,

- a service centre through which it is possible to enter and update information (or CMS),

- the standardization of displayed information in a variety of distribution interfaces,

- the integration of different products

- individual organization of information, depending on user's interests (filtering and sorting),

- booking accommodation and other tourism products and services.

The analyses of several DMS providers (e.g. New Mind, Tiscover, Gulliver, Co-

3 Travel planners are typical tools of destination marketing allowing users to plan what and when they will do during their holidays. (Slivar Tiganj, 2012) 
degn, Desti.ne and Opera21) revealed three key common components of DMS: CMS (Content Management System)4 , CRM and online booking (Slivar Tiganj, 2013).

Not many DMS were developed to service guests' needs in the visit phase. Indeed one of the major criticisms of DMS is related to the lack of true information needs of the industry, since many were developed by publicly funded DMOs with poor collaboration with tourism services providers (Ritchie and Ritchie 2002, Talaat, Fahmi and Marzouk, 2015) as well as final users. The second key challenge in developing DMS systems refers to the ranking of information (Talaat, Fahmi and Marzouk, 2015 ). Some DMS might be privately owned, as it is the case in the following semiDMS - Guest.net - more focused on economic effects than other sustainable goals.

Overall, DMS sets the information base of destination management by enabling to use destinations' information to support product development, promotion, online distribution and customer relationships. There are various directions to further develop in-destination systems into recommendation systems: based on demographics, content, collaborative filtering, knowledge, utility and hybrid systems (Noguera, Barranco, Segura, Martinez, 2012). For instance, the SoCoMo umbrella concept (Buhalis, Foerste, 2015) adds to mobile marketing also the social and contextual component, whereas the latter includes already location-based marketing principles.

In the main areas of GIS applications (mapping, measurement, monitoring, modelling and management), there are many influences of tourist activities (Stankov, Đurđev, Marković, Arsenović, 2012), such as DMO’s. Whereas, according to Pahernik (2006) GIS in the narrowest sense is a computer tool for creating and analysing geographic objects, i.e. occurrences and events in space.

\section{CASE STUDY: GUEST.NET AT MAISTRA ING}

\subsection{The context: Maistra Inc. promotional activities}

Headquartered in Rovinj, Maistra Inc was established in March of 2005, having inherited 50 years of experience in the tourism business. The company owns 10 high quality hotels, 8 tourist resorts and 6 camping sites situated at prestigious locations in Rovinj and Vrsar, two Istrian tourist centres of exceptional natural and cultural/ historic values. The total portfolio capacity amounts to nearly 34,000 guests, resulting in the figures of approximately $5 \%$ of the tourist results of Croatia, and slightly more than $15 \%$ of the tourist results of Istria (Maistra, 2018).

By continuously innovating and redesigning the tourist offer with the use of modern technology, Maistra attracts new clients and business partners, which makes it one of the most competitive on the Croatian tourism market. By cooperating with the DMOs and the city administration, Maistra contributes to a greater promotion

4. CMS enables the management of dynamic websites without the need of specific technical knowledge. It is also know as back-end, whereas websites that users see, are therefore, called front-ends. 
of the company, but also of the tourist destinations of Rovinj and Vrsar, where the company operates. Maistra's marketing communication is primarily directed to increase revenue and demand, while striving to achieve a positive image and market recognition.

The prerequisite for the realization of its strategic and operational goals in the promotion is the optimization of internal communication among its departments mainly: operations, marketing, properties (hotels, resorts and campsites) and quality management functions and their continuous cooperation. The core responsibility of the marketing function is to support the function of operations as an expert service and to create all the prerequisites for a quality promotion of the total offer of additional services (e.g. F\&B, excursions, Spa, etc.). 5

Informing tourists about Maistra's offer, prior to their arrival to the destination, is primarily performed through official acquisitional websites (www.maistra.com, www.campingrovinjvrsar.com www.montemulinihotel.com and www.lonehotel. com). By participating in fairs and workshops on target markets, Maistra expands its communication with the interested public. Video clips provide a better insight into their own tourist offer and of the tourist destinations.

In order to ensure the high quality of its offer, Maistra performs various in-house promotion activities (e.g. flyers, internal television, sales staff in the form of guest relations, etc.) as part of providing information to guests within its facilities. The underlying goal of in-house promotion is to increase the sale of additional services within Maistra's facilities by providing timely and accurate information on the offer and special prices. The reliability of provided information is of critical importance, since verified sources of information eliminate the risk of getting inaccurate information.

The basic marketing tools used for the promotion of Maistra's properties and services are printed materials: various flyers, brochures, postcards and coupons with stimulating discounts, a corporate magazine, as well as interactive TV and a new media for in-house promotion - Guest.net. Printed promotional materials are divided into three groups: general promotional printed materials (image directory of hotels and resorts, directory catalogue of camping offers, Maistra Gourmet leaflet, congress brochure, Monte Mulini brochure, individual promotional brochures), standard propaganda-informational material (hotel standards for 4-star hotels, hotel standard for hotel Lone etc.) and other promotional materials (e.g. MaistraCompany magazine, cookbook Monte Mulini etc.). The first two groups of printed promotional materials relate to the promotion of hotel services, while the last group of (other) promotional materials include a wider area including the promotion of the tourist destinations.

MaistraCompany magazine represents a kind of in-house PR activity, and is available to guests in their hotel rooms. The magazine is a result of collaboration of journalists, photographers, translators and lecturers, publishers and others. The aim

5 Maistra: internal data. 
of the magazine is to promote new services offered by Maistra, promote the destinations and events, culture and gastronomy. The journal is printed in two languages (Croatian and English) in three editions and printed in 25,000 copies.

As the gastronomic offer is one of the key elements of Maistra's overall offer, the marketing department is directly involved in the process of creating and defining products as well as programs of special interest which include gastronomy. The media plan defines advertising through specialized journals and reputable gastronomic guides, and advertising through local radio stations and specialized (gastronomy) portals. In addition to advertising in the media, the company advertises in the destinations they operate in.

\subsection{Case study: Guest.net}

With the development of internet access through various devices in the destination (via laptops, smartphones, info kiosks and similar), Maistra saw the opportunity to use the internet for the purpose of in-destination and in-house marketing communication. The company has therefore introduced a new media in its promotion - the so-called Guest.net system. It is an interactive in-house and in-destination information platform which provides Maistra's guests with more detailed information about tourist products at their disposal, as well as various service information. The focus is on the tourist products, services and events provided in Maistra's facilities, in the destinations of Rovinj and Vrsar and wider in the region of Istria.

Guest.net uses geolocation technology which recognizes the location from which a guest connects to the Internet (Wi-Fibased) and thanks to a modular homepage structure, provides guests those information which are most relevant to the micro location the guest is located in. The system is actually a website that search engines do not index (no index, no follow tag is set). Thus Guest.net can be accessed only from all Maistra's info points where it is set as a home page (push technique) and thought laptops and other guests' devices that use the property's wireless network to access the Internet. In both cases, Guest.net is the home page displayed. The use of Guest.net is free of charge.

Beyond Guest.net, Maistra's tourists can collect information through the television channel in all Maistre hotel rooms, in communication with reception staff and through various offline tools.

The content of Guest.net is organized by categories (sports, wellness, events, restaurants and bars) and available in several languages (English, German, Italian and Croatian). The search functionality is available also through Google Maps. Some content is collected in the form of automatic download of content from specialized services i.e. Content Partnerships (e.g. currency converter, weather forecast) also known as mash ups.

By further surfing within the website, guests will find information on events and services in other Maistra's facilities, primarily those located close to them, within 
the destination they are in, and even in the whole region of Istria. The website design uses colours to intuitively reveal the proximity of certain contents, as the colours are pale if the content is more distant. Regarding the ranking issue identified by Talaat, Fahmi and Marzouk (2015), in case of two same types of amenities, equally distant, the least frequented one is displayed to users first; in order to increase economic profitability and indirectly adequately affecting visit management. More contact options are also available to users.

Maistra presents content from its own offer as well as events organized in its properties. In addition, since Maistra, as a socially responsible company, participates in a number of projects in the destinations in which it operates, Guest.net also promotes events in which Maistra is involved as a co-organizer or sponsor in cooperation with DMOs, the towns it operates and other stakeholders. Beside those, it also provides service information such as ATMs, shops, gas stations, etc. connected to the interactive map at Guest.net.

"Unlike our main websites that are primarily intended to represent Maistra and its offer to attract guests to our properties, Guest.net is intended for those guests who already reside in Maistra's facilities. We will now be able to inform them more effectively. Moreover, they will be able to search, select and inform them about the services and events they are actually interested in. The goal of this project is to enrich the stay of guests with additional amenities because we believe that we will achieve that our guests feel even more comfortable and even more satisfied" they say in Maistra.

The Guest.net system initially functioned only for desktops and laptops, but quickly adapted to display via mobile phones, and plans to expand via the internal television channel in all rooms of Maistra's facilities. The development potential is also seen in customizing the site and displaying it on various info kiosks in the destination, involving the public sector (primarily the DMOs) and by including other public services and advertising other tourist products and services of the destination, in partnership with relevant tourism providers.

With the introduction of Guest.net, Maistra introduces a new quality in the communication with its guests. In addition to the existing forms of information, guests will also have access to fast, comprehensive, multi-media information with a range of accompanying content, continually, 24, hours a day, seven days a week.

The Guest.net project was launched on June 24, 2009, and the website was activated on July 1, 2010, after which the system was upgraded and updated. The marketing push technique was applied (guest.net is the homepage when accessing the internet from Maistra's facilities); therefore, a large bounce rate (a web metric that denotes the percentage of users who viewed only one page and then left the web site) of over $50 \%$ was expected. As opposed to the solution of travel planners tools in the form of mobile applications or web sites that users consciously visit / install (based on the principle of pull technique). On the other hand, given the push technique, the promotion of Guest.net to the guests of the Maistra hotel chain is not necessary. 
Unfortunately, because of the reorganization of the business and the inadequacy of personnel resources, the Guest.net project is temporarily shut down.

\section{DISCUSSION AND CONCLUSION}

Marketing communication is associated with promotion in the pre-arrival phase mainly and lately with post staying behaviour, thus the set of tools and techniques used in the first and last phase of the consumer buying life cycle has been researched widely. The post-visit phase is having a revival thanks to social media and reviews. The middle phase, in-destination communication, however, remains quite neglected, although, location and proximity marketing and local search are improving this issue. In this phase, guests want to engage into experiencing the main motivation drivers hence collect information about the destination, its activities and attractions available on spot. Those information must be accurate, reliable and provided at the right moment. Traditionally, the most dominant sources of information were printed materials and human interactions. The widespread use of smartphones and mobile devices is switching content distribution to e-communication with users.

The sovereignty over trustworthy, complete and high quality information about the tourism destination should be provided by DMOs, as to avoid for tourists the hassle of visiting various platforms - apps and websites from different providers (comparing different data) and the loss of time and effort. Slowly, tourism providers are moving into communicating with guests during their stays. In the observed case study, the DMOs of the tourist destinations Rovinj and Vrsar did not provide any in-destination, local e-information to their guests. A hotel company (Maistra) has overtaken its role as a promoter of its own products and partially of the destinations as it has included in its system the distribution of information and content under the DMO's jurisdiction. In that sense, the Guest.net platform is almost a kind of DMS system for the destinations Rovinj and Vrsar where the hotel company Maistra operates. This situation is not unexpected nor uncommon, given major budgets of hotel chains compared to those of DMOs, having a financial interest and the opportunity to reach tourists.

Since preferences of users towards formats of information are different, ICT should not be the only option of informing tourists, it depends upon the target market. Creating unique regional information in different formats (Ritchie and Ritchie, 2002) with already offered itineraries according to the interests of tourists should enable the concentration of more detailed information in one place and thus reduce the effort of tourists.

A wider insight into existing attractions and the provision of adequate information at the destination allows tourists to visit more of such points of interest than they intended before reaching the destination. This might have a positive effect on the length of stay of tourists in order to visit all the attractions they did not know earlier, 
on an increase in tourism expenditures, affect their willingness to revisit the destination, trigger loyalty and their propensity to recommend visiting it.

Given the identified hard information gap, Klante, Kroschel and Bolls model (2004) should thus be expanded by adding an additional step after the first (orientation) phase: the organisation of the visit which would support decision making by providing adequate information necessary for planning visiting a single or more POIs. In the latter case, the functionality of a trip planner is advisable. Another contribution to theory is the list of typical sources of information about a tourist destination to users during the visit phase.

In relation to the previously said, the topic of in-destination information should be more researched in order to make marketing professionals more helpful towards meeting the goals of tourists during the visit phase.

Guest.Net is an interactive in-house and in-destination information platform that provides Maistra's guests with more detailed information on tourist products and services at their disposal, as well as various service information. As soon as a Maistra's guest connects to the Internet, either via its own device either via a computer in an Internet Corner at Maistra's properties, the homepage tailored to the location will be displayed. The system will recognize the location from which the guest connects and the initial information provided will be referenced precisely to the property where these services and events are located in that facility. Solutions like Guest.net are desirable for hotel chains operating in a particular tourist destination, to target their guests persuading them to use chain's services based in nearby hotels, resorts, camping sites, restaurants, bars, entertainment centres, spas etc.

The contribution for practitioners is obviously reflected in gaining knowledge about providing location-based information to guests of tourist facilities during their stay, especially for chains with properties located within reach. Adequate assessment of tourist needs is a prerequisite for that as well as an effective use of such researches. Tourism providers should acknowledge the importance of mobile marketing and LBS (Location Based Services) and include them in promotional activities.

The main disadvantage of this study is the case study format, thus more research is advisable. The findings are reported on a guest service case study in a European context, hence should be repeated also elsewhere, to support generalisation. Although the efficiency of Guest.net scores well in terms of low cost promotion, faster and easier reach of tourists, as an additional feature of this research, it would be worth comparing the efficiency of other sources of information and other formats. Also, the study does not cover the attitudes of tourist demand, their information search process in the destination (crucial for adjusting to customers' needs) and the wider impacts - social and economic effects of Guest.net's in-destination distribution of information. Furthermore the quality of the solution was not explored i.e. the key factors affecting the level of usage of GIS in tourism were usefulness and playfulness (Chang, Caneday, 2011), the same could be further researched in relation to DMS. 
The provision of in-situ information in the adequate depth, format and in time, will benefit all stakeholders in the tourism destination. Along with obvious benefits to tourists in terms of accommodation, satisfaction of stay, increase in extra-spending, it also helps in relieving the reception functions of informing guests. Since it's a push solution, it's not necessary to overburden the in-house promotion budget, as opposed to, for example, mobile apps formats or similar contents as a pull tools. 


\section{REFERENCES}

Buckowski, A. (2011): Location based marketing - Introduction http://geoawesomeness.com/ knowledge-base/location-based-marketing/location-based-marketing-introduction/ (28.9.2018.)

Buhalis, D., Foerste, SoCoMo marketing for travel and tourism: Empowering co-creation of value, Journal ofDestinationMarketing\&Management 4 ( 2015$): 15^{1-161}$

Chaffey, D. Mayer, R. Johnston, K. et al.: "Internet marketing - Strategy, Implementation and Practice", trece izdanje, Prentice Hall - Financial Times, Harlow, 2006.

Chang, G. , Caneday L., Web-based GIS in tourism information search: Perceptions, tasks, and trip attributes, Tourism Management vol. 32, (2011): 14,35-14,37

Garača, N.: "Marketinška komunikacija i imidž", skripta iz kolegija "Poslovna komunikacija", Visoka škola za menadžment u turizmu i informatici, Virovitica, 2008., http://vsmti.hr/component/option,com_ docman/task,doc_view/gid,51/Itemid,35/, (28.4. 2009.)

Essayad, A. "Design and implementation of a platform for location-based services: a case study of GIS of archaeological and handicraft of Fez Medina", IJCSI International Journal of Computer Science Issues, Vol: 8(3), (2011): 524-530

Internal data of Maistra Inc.

Klante, P. Krösche, J.and Boll, S., Accessights - a multimodal location-aware mobile tourist information system. In International Conference on Computers Helping People with Special Needs(ICCHP), Paris, France, Springer-Verlag, (2004): 187-294

Kotler P. and Keller K.L., Marketing Management (13th edn). Pearson Education International, Prentice Hall, 2009.

Križman Pavlović, D., Marketing turističke destinacije, Sveučilište Jurja Dobrile u Puli Odjel za ekonomiju i turizam "dr. Mijo Mirković", 2008.

Gerdes, H.: "ANational Destination Management System (DMS) based on the examples of Germany and Switzerland", Information and Communication Technologies in Tourism, WienlNew York: SpringerVerlag, (1998): 24,8 - 257

Law, R., Buhalis, D., Cobanoglu, C. (2014) Progress on Information and Communication Technologies in Hospitality and Tourism, European Journal of Marketing 26(5), DOI: 10.1108/IJCHM-०8-2013-०367

Levesque, N., Boeck, H., Proximity marketing as an enabler of mass customization and personalization in a customer service experience. In: Managing Complexity. Springer International Publishing, (2015): $4,05-4,20$

Li, S. (2011). Location-based Services Marketing : Extracting and using location data for marketing, Master Thesis, Royal Institute of Technology, School of Computer Science and Communication.

Maistra Inc. https://www.maistra.com/about-us/company-profile (22.5.2018.)

Noguera, J.M., Barranco, M. J., Segura, R.J., Martínez, L., A mobile 3D-GIS hybrid recommender system for tourism, Information Sciences 215, (2012): 37-52

O'Connor, P. and Frew, A. J.: "The Future of Hotel and Electronic Distribution - Expert and Industry Perspectives", Cornell Hospitality Quarterly, Vol. 43., No. 3., http://www.google.hr/ url? sa=t\&source=web\&cd=4\&ved=oCDQQFjAD\&url=http $\% 3 \mathrm{~A} \% 2 \mathrm{~F} \%{ }_{2} \mathrm{Fwww} \cdot$ harald-roebig. de $\%{ }_{2}$ FSCE $\%{ }_{2}$ FLiterature $\% 2520$ Research $\% 2520$ Papers $\% 2$ Felectronic $\% 252$ odistribution. pdf\&ei=8pFoTpavC4,GdOrWntccL\&usg=AFQjGNGQvrAogTujGpOzLQhRlFjWzUfIXg (8.9.2011.): 33-45 
Ojala, T., Kruger, F., Kostakos, V., Valkama, V., Two field trials on the efficiency of unsolicited Bluetooth proximity marketing. Proc. of Mobile and Ubiquitous Multimedia (MUM). ACM, Ulm, Germany, (2012): 1-4

Ortega E. and Rodrigues B., Information at tourism destinations. Importance and cross-cultural differences between international and domestic tourists. Journal of Business research, 60 (2), (2007): 14,6-152

Pahernik M., Uvod u geografsko informacijske sustave, Zapovjedništvo za združenu izobrazbu i obuku "Petar Zrinski", Zagreb, 2006.

Ritchie, R.J.B., \& J.R.B., Ritchie, A Framework for an Industry Supported Destination Marketing Information System. Tourism Management, 23(5), (2002): 439-454

Ružić, Turkalj, Biloš, E-marketing, Osijek : Sveučilište Josipa Jurja Strossmayera, Ekonomski fakultet, 2014 .

Schultz, D.E. and Schultz, H.F., IMC, the next generation: five steps for delivering value and measuring financial returns, McGraw-Hill, 2004.

Senečić, V., Vukonić, B., Marketing u turizmu, Mikrorad d.o.o., Zagreb, 1997.

Slivar Tiganj, I., Strategije komuniciranja turističkih destinacija putem interneta, Sveučilište J. Dobrile, Pula, PhD thesis, 2012.

Slivar Tiganj, I. „DMO's Websites Evolving into Destination Management Systems and Perspectives towards Sustainable Tourism Development", Sustainable tourism: An Interdisciplinary Approach, J. Dobrila University of Pula, Department of Economics and Tourism, (2013): 259-277

Stankov, U., Đurđev, B. , Marković V., Arsenović, A., Understanding the importance of GIS among students of Tourism management, Geographia Technica, No. 2, (2012): 68 - 74

Kesić, T.: "Marketinška komunikacija", Mate, Zagreb, 1997.

Talaat, N. M., Fahmi, T. M., Marzouk, A. M., The Impact of WiMAX on Developing Location-based Services in Tourism, Journal of Faculty of Tourism and Hotels, Fayoum University Volume (9), Issue (1) - March, 2015.

UNESCO (undated): World heritage Sustainable tourism online toolkit - Guide 5: Communicationg with visitors communicationhttp://whc.unesco.org/sustainabletourismtoolkit/guides/guide-5communicating-visitors, $25 \cdot 5 \cdot 2018$.

Vavrečka, V., Mezuláník, J., Marketing communications in tourism - trends and reality, Маркетинг i менеджмент інновацій, № 2., (2016): 80-96

Voght, C.A., Stewards, S. I., Affective and Cognitive effects of Information Use over the course of a Vacation, Journal of Leisure Research, 3o (4), (1998): 498-520

Wang, D., Park, S. and Fesenmaier, D.R., "The role of smartphones in mediating the touristic experience", Journal of Travel Research, Vol. $5^{1}$ No. 4, (2012): $37^{1}-387$

Wayne, N.: "Hi-Line: A Case Study of a Working Computerized Central Reservation Office in the Public Sector Tourism", Information Technology in Public Tourism Offices, Conference Proceedings, Assisi, Italy, 1991.

Werthner, H. and Klein, S.: „ICT and the changing landscape of global tourism distribution“, Electronic Markets, Vol. 9. No. 4., http://old.geog.psu.edu/courses/geog497b/Readings/Werthner\&Klein_Tourism. $\operatorname{pdf}(3 \circ .3 .2010):. 256-262$

WTO: "Handbook on E-marketing - a Practical Guide for Tourism Destinations", WTO Madrid, Spain, 2008. 
